\title{
MENAKAR HASIL PENDIDIKAN KARAKTER TERINTEGRASI DI SMP
}

\author{
Gendon Barus \\ Universitas Sanata Dharma Yogyakarta \\ email: bardon.usd@gmail.com
}

\begin{abstract}
Abstrak: Penelitian ini bertujuan untuk mengevaluasi keterlaksanaan pendidikan karakter terintegrasi di SMP dan mengukur capaian hasilnya. Pelaksanaan pendidikan karakter terintegrasi pada lima kota di Indonesia belum menunjukkan hasil yang menggembirakan. Selain berhenti hanya pada tataran kognitif, muatan nilai-nilai karakter yang diintegrasikan ke berbagai mata pelajaran sifatnya hanya "tempelan", sekadar ditulis di Rencana Pelaksanaan Pembelajaran, tanpa eksplisitasi kongkret dalam pelaksanaan. Sebagian besar guru mata pelajaran yang dititipi muatan pendidikan karakter secara terintegrasi mengalami keterbatasan kemampuan mendeskripsikan, mengaktualisasikan, dan membumikan pelaksanaan misi itu. Pada sisi lain, kehadiran dan peran konselor yang secara khusus dibekali untuk peran transmitter pendidikan "hati" (pendidikan karakter) tidak dilibatkan sama sekali, sebagaimana tampak pada sebagian besar SMP di Indonesia tidak menyediakan jam layanan bimbingan klasikal. Gagasan penelitian ini diharapkan menginspirasi kerangka kerja ditemukannya model alternatif pendidikan karakter yang berorientasi pada terbangunnya kemitraan-kolaboratif profesional antara konselor/Guru BK dengan guru mata pelajaran dalam implementasi pendidikan karakter di sekolah.
\end{abstract}

Kata Kunci: pendidikan karakter, bimbingan klasikal, peran konselor

\section{MEASURING THE RESULT OFTHE INTEGRATED CHARACTER EDUCATION IN JUNIOR HIGH SCHOOLS}

\begin{abstract}
This study was aimed to evaluate the implementation of the character education in Junior High School and to measure the result. The implementation of integrated character education in Junior High School in several cities in Indonesia has not shown satisfactory result. It was only at the cognitive level. The contents of character values integrated into a variety of subjects were just like "patches". They are only written in a lesson plan, without realization in the implementation. Most of the subject teachers who are entrusted with the content of character education integrated into the learning process, had limited ability to describe, actualize, and implement the mission. On the other hand, the counsellor who was specifically equipped with the transmitter role of character education was not involved at all. This could be seen in most junior high schools in Indonesia which did not provide a classical guidance service schedule. This study is expected to inspire the finding of an alternative of the character education model oriented to professional collaborative partnership between the counsellors and teachers implementing the character education.
\end{abstract}

Keywords: character education, classroom guidance, the role of counsellor

\section{PENDAHULUAN}

Kementerian Pendidikan Nasional telah mengembangkan grand design pendidikan karakter untuk setiap jalur, jenjang, dan jenis satuan pendidikan. Grand design menjadi rujukan konseptual dan operasional pengembangan, pelaksanaan, dan penilaian pada setiap jalur dan jenjang pendidikan. Konfigurasi karakter dalam konteks totalitas proses psikologis dan sosialkultural tersebut dikelompokan dalam olah hati (spiritual and emotional development), olah pikir (intellectual development), olah raga dan kinestetik (physical and kinestetic development), dan olah rasa dan karsa (affective and creativity development). Pengembangan dan implementasi pendidikan karakter dilakukan dengan mengacu pada grand design tersebut dengan melibatkan seluruh komponen sekolah.

Efektivitas pendidikan karakter terintegrasi yang dikemas dalam Panduan Pendidikan 
Karakter di Sekolah Menengah Pertama (Direktorat Pembinaan SMP, Ditjenmandikdasmen, 2010) layak dipertanyakan. Berhasil, atau gagalkah? Jika berhasil, mengapa semakin marak perilaku berkarakter buruk pada anak belasan tahun ini? Jika gagal, bagian mana yang inefektif dan apa hambatannya?

Buchori (2007:4) mempertanyakan, apa yang salah dengan pendidikan karakter kita? "Pendidikan watak" diformulasikan menjadi pelajaran agama, pelajaran kewarganegaraan, atau pelajaran budi pekerti, yang program utamanya ialah pengenalan nilai-nilai secara kognitif semata. Padahal, pendidikan karakter seharusnya membawa peserta didik ke pengenalan nilai secara kognitif, penghayatan nilai secara afektif, dan akhirnya ke pengamalan nilai secara nyata.

Permasalahannya adalah, pendidikan karakter di sekolah, khususnya di SMP di seluruh tanah air selama ini baru menyentuh pada tingkatan pengenalan norma atau nilai-nilai, dan belum pada tingkatan internalisasi dan tindakan nyata dalam kehidupan sehari-hari (Suyanto, 2011:8). Perlu dilakukan evaluasi komprehensif tentang hal-hal seperti berikut. (1) Sejauh mana keterlak-sanaan pendidikan karakter terintegrasi di SMP? (2) Hambatan-hambatan apa yang ditemukan dalam pelaksanaan pendidikan karakter terintegrasi di SMP? (3) Sejauh mana capaian hasil pendidikan karakter yang telah berlangsung dengan sistem terintegrasi di SMP?

Permasalahan pendidikan karakter yang selama ini ada di SMP perlu segera dikaji: di mana kelemahannya, apa hambatannya, seberapa jauh hasilnya; dan jika secara empirik diketahui belum memuaskan, maka perlu dicari altenatif-alternatif solusinya, serta perlu dikembangkan suatu model pelaksanaannya secara lebih operasional dan efektif sehingga mudah diimplementasikan di sekolah. Sekolah-sekolah yang selama ini telah berhasil melaksanakan pendidikan karakter dengan baik dapat dijadikan sebagai the best practices model yang menjadi contoh untuk disebarluaskan ke sekolahsekolah lainnya.

Meskipun efektivitasnya masih jauh dari hasil yang diharapkan, kebijakan untuk memosisikan dan memfungsikan semua guru mata pelajaran sebagai "pengajar karakter" siswa di SMP tanpa melibatkan peran konselor sekolah saat ini masih harus terpaksa diterima sebagai realitas (periksa Buku Panduan Pendidikan Karakter di Sekolah Menengah Pertama, 2010). Melepaskan guru dari peran sebagai agen transmitter nilai-nilai karakter dalam hal ini memang sesungguhnya tidak disarankan, namun mengoptimalkan peran-fungsi konselor/guru BK sebagai mitra kolaboratif profesional dengan guru mata pelajaran dalam menjalankan peran tersebut adalah sebuah keharusan. Untuk itu, perlu ditemukan model pelaksanaan pendidikan karakter di SMP yang lebih efektif dengan memfungsikan konselor/guru BK sebagai mitra kerjasama profesional dengan guru mata pelajaran melalui layanan bimbingan klasikal kolaboratif dengan pendekatan experiential learning sebagaimana digagas dalam penelitian pengembangan ini.

Penelitian ini bertujuan untuk menganalisis secara evaluatif tentang implementasi, berbagai hambatan, dan hasil-hasil pendidikan karakter terintegrasi pada beberapa SMP di Indonesia, sebagai preliminary study untuk mengembangkan sebuah model pendidikan karakter yang lebih efektif dengan mengoptimalkan peran konselor sekolah melalui layanan bimbingan klasikal kolaboratif dengan pendekatan $e x$ periential learning. Kajian ini sangat relevan dan aktual dilaksanakan dalam koridor optimalisasi pelayanan BK di SMP (Permendikbud No. 81 A Tahun 2013 tentang Implementasi Kurikulum 2013), peningkatan profesionalisme guru menuju perbaikan mutu pendidikan dasar, school reform movement, otonomi pendidikan dalam konteks otonomi daerah, aktualisasi MPBS, student centred learning-oriented, kuatnya kebutuhan untuk revitalisasi nilai-nilai dalam dunia pendidikan, tuntutan character education, dan menyongsong implementasi kurikulum 2013 yang syarat muatan pembentukan sikap dan nilai menuju pencapaian standar kompetensi peserta didik sesuai amanah standar nasional pendidikan dalam upaya membangun manusia Indonesia seutuhnya dan peningkatan daya saing bangsa. 


\section{Pendidikan Karakter Kolaboratif}

Kolaborasi guru mata pelajaran dengan konselor/guru BK dalam mengoptimalkan keterlaksanaan dan hasil pendidikan karakter di SMP di seluruh tanah air semakin mendesak dilakukan. Melalui layanan dasar bimbingan (satu dari empat komponen program BK Komprehensif) diharapkan sekolah dapat memadukan pendidikan intelektual dan pendidikan nilai/karakter secara lebih seimbang (Raybum, 2004:67) sehingga kebutuhan-kebutuhan psikososial peserta didik untuk menjamin kelancaran tugastugas perkembangan dan penguatan karakter pribadi secara lebih komprehensif, harmonis, dan utuh dapat lebih terlayani.

Khusus dalam konteks pendidikan karakter terintegrasi di SMP (Panduan Pendidikan Karakter di Sekolah Menengah Pertama, 2010) yang penyelenggaraannya dibebankan kepada guru mata pelajaran, permasalahannya adalah apakah para guru telah mengeksplisitkan muatan karakter ke dalam pembelajaran? Gagasan ini menawarkan suatu model pendidikan karakter di SMP, terutama dengan mengoptimalkan keterlibatan konselor (guru BK) sebagai tenaga kependidikan yang berbekal khusus keilmuan profesional di bidang helping profession. Guru BK telah dibekali kompetensi dalam mendisain dan melaksanakan program pengembangan diri bidang-bidang pribadi, sosial, belajar, dan karier, termasuk di dalamnya kemahiran dalam mendesain dan melaksanakan pendidikan nilai-nilai atau pendidikan karakter melalui layanan bimbingan klasikal. Model ini mengemban misi penyajian pendidikan karakter dilakukan secara kolaboratif (antara konselor/ guru BK dengan guru mata pelajaran) dengan mengaplikasikan pendekatan experiential learning. Defisit kemampuan guru mata pelajaran dalam mendesain, mengoperasionalkan, dan explisitasi pelaksanaan pendidikan karakter terintegrasi dalam pembelajaran dapat diatasi melalui model kolaborasi ini.

\section{Paradigma Baru Pendidikan dan Urgensitas Pendidikan Karakter di SMP}

Pemerintah melalui Kementerian Pendidikan Nasional tengah menggalakkan kembali pembangunan karakter bangsa. Undang-Undang No 20 Tahun 2003 tentang Sistem Pendidikan Nasional pada Pasal 3, sejatinya telah mengamanatkan bahwa pendidikan nasional berfungsi mengembangkan kemampuan dan membentuk karakter serta peradaban bangsa yang bermartabat dalam rangka mencerdaskan kehidupan bangsa. Pendidikan nasional bertujuan untuk berkembangnya potensi peserta didik agar menjadi manusia yang beriman dan bertakwa kepada Tuhan Yang Maha Esa, berakhlak mulia, sehat, berilmu, cakap, kreatif, mandiri, dan menjadi warga negara yang demokratis serta bertanggung jawab. Berdasarkan fungsi dan tujuan pendidikan nasional, jelas bahwa pendidikan karakter di setiap jenjang, termasuk Sekolah Menengah Pertama (SMP) harus diselenggarakan secara sistematis guna mencapai tujuan tersebut.

Pengembangan manusia sebagai mana diamanatkan dalam tujuan pendidikan nasional tersebut menunjuk pada pembentukan karakter peserta didik sehingga mampu bersaing, beretika, bermoral, sopan santun, menghargai nilainilai kemanusiaan, dan mampu berinteraksi dengan masyarakat. Berdasarkan penelitian di Harvard University Amerika Serikat, ternyata kesuksesan seseorang tidak ditentukan sematamata oleh pengetahuan dan kemampuan teknis (hard skill) saja, tetapi lebih oleh kemampuan mengelola diri dan orang lain (soft skill). Penelitian ini mengungkapkan bahwa kesuksesan hanya ditentukan sekitar $20 \%$ oleh hard skill dan sisanya $80 \%$ oleh soft skill. Bahkan, orangorang tersukses di dunia bisa berhasil dikarenakan lebih banyak didukung kemampuan soft skill daripada hard skill (Sudrajat, 2011:2). Hal ini mengisyaratkan bahwa mutu pendidikan karakter peserta didik sangat penting untuk ditingkatkan.

Peraturan Pemerintah Nomor 17 Tahun 2010 tentang Pengelolaan Penyelenggaraan Pendidikan pada Pasal 17 Ayat (3) menyebutkan bahwa pendidikan dasar, termasuk Sekolah Menengah Pertama (SMP) bertujuan membangun landasan bagi berkembangnya potensi peserta didik agar menjadi manusia yang (1) beriman dan bertakwa kepada Tuhan Yang Maha Esa; 
(2) berakhlak mulia, dan berkepribadian luhur;

(3) berilmu, cakap, kritis, kreatif, dan inovatif;

(4) sehat, mandiri, dan percaya diri; (5) toleran, peka sosial, demokratis, dan bertanggungjawab. Berdasarkan hal tersebut, jelas bahwa tujuan pendidikan di setiap jenjang, termasuk SMP sangat berkaitan dengan pembentukan karakter peserta didik.

Menyadari pentingnya karakter, dewasa ini banyak pihak menuntut peningkatan intensitas dan kualitas pelaksanaan pendidikan karakter pada lembaga pendidikan formal. Tuntutan tersebut didasarkan pada fenomena sosial yang berkembang, yakni meningkatnya kenakalan remaja dalam masyarakat, seperti perkelahian massal, premanisme, tindak kekerasan, penipuan, pencurian, seks bebas, dan berbagai kasus dekadensi moral lainnya. Bahkan di kotakota besar tertentu, gejala tersebut telah sampai pada taraf yang sangat meresahkan. Terdapat kecenderungan bahwa emotional behavior tampaknya meningkat di semua lapisan masyarakat kita (Astuti, 1999:93). Oleh karena itu, lembaga pendidikan formal sebagai wadah resmi pembinaan generasi muda diharapkan dapat meningkatkan peranannya dalam pembentukan kepribadian peserta didik melalui peningkatan intensitas dan kualitas pendidikan karakter.

\section{Tujuan Pendidikan Karakter di SMP}

Pendidikan karakter bertujuan untuk meningkatkan mutu penyelenggaraan dan hasil pendidikan di sekolah yang mengarah pada pencapaian pembentukan karakter dan akhlak mulia peserta didik secara utuh, terpadu, dan seimbang, sesuai standar kompetensi lulusan. Melalui pendidikan karakter diharapkan peserta didik SMP mampu secara mandiri meningkatkan dan menggunakan pengetahuan, mengkaji dan menginternalisasi serta mempersonalisasi nilai-nilai karakter dan akhlak mulia sehingga terwujud dalam perilaku sehari-hari (Suyanto, 2010:3).

Karakter dikembangkan melalui tahap pengetahuan (knowing), pelaksanaan (acting), dan kebiasaan (habit). Dengan demikian, diperlukan tiga komponen karakter yang baik (components of good character), yaitu moral know- ing (pengetahuan tentang moral), moral feeling atau perasaan (penguatan emosi) tentang moral, dan moral action atau perbuatan bermoral. Dimensi-dimensi yang termasuk dalam moral knowing yang akan mengisi ranah kognitif adalah kesadaran moral (moral awareness), pengetahuan tentang nilai-nilai moral (knowing moral values), penentuan sudut pandang (perspective taking), logika moral (moral reasoning), keberanian mengambil sikap (decision making), dan pengenalan diri (self knowledge). Moral feeling merupakan penguatan aspek emosi peserta didik untuk menjadi manusia berkarakter. Penguatan ini berkaitan dengan bentuk-bentuk sikap yang harus dirasakan oleh peserta didik, yaitu kesadaran akan jati diri (conscience), percaya diri (self esteem), kepekaan terhadap derita orang lain (emphaty), cinta kebenaran (loving the good), pengendalian diri (self control), kerendahan hati (humility). Moral action merupakan perbuatan atau tindakan moral yang merupakan hasil (outcome) dari dua komponen karakter lainnya.

Untuk memahami apa yang mendorong seseorang dalam perbuatan yang baik (act morally) maka harus dilihat tiga aspek lain dari karakter, yaitu kompetensi (competence), keinginan (will), dan kebiasaan (habit). (Direktorat Pembinaan SMP, 2010:19-20). Tahapan ini sejalan dengan pendapat Lickona (2014:74) yang mengemukakan bahwa komponen-komponen karakter yang baik terdiri dari tiga bagian yang saling terkait, yaitu pengetahuan tentang moral (moral knowing), perasaan moral (moral feeling), dan aksi moral (moral behavior). Dalam kaitan itu, karakter yang baik bermula dari mengetahui kebaikan, mencintai atau menginginkan kebaikan, dan akhirnya dengan tekad yang sungguh-sungguh orang berjuang untuk melakukan kebaikan.

Pelayanan bimbingan dan konseling merupakan bagian integral dari sistem pendidikan nasional. Jika pendidikan karakter mendapatkan bobot perhatian serius dalam sistem pendidikan nasional, maka orientasi, tujuan, dan pelaksanaan BK juga seharusnya ditempatkan sebagai bagian dari orientasi, tujuan dan pelaksanaan pendidikan karakter tersebut. Program bimbingan 
dan konseling di sekolah merupakan bagian inti pendidikan karakter yang dilaksanakan dengan berbagai strategi pelayanan dalam upaya mengembangkan potensi peserta didik untuk mencapai kemandirian, dengan memiliki karakter pribadi-sosial tangguh yang dibutuhkan saat ini dan masa depan.

Pekerjaan bimbingan dan konseling adalah pekerjaan berbasis nilai, layanan etis normatif, dan bukan layanan bebas nilai. Seorang konselor perlu memahami betul hakekat manusia dan perkembangan-nya sebagai makhluk sadar nilai dan perkembangannya ke arah normatif-etis. Seorang konselor harus memahami perkembangan nilai, namun seorang konselor tidak boleh memaksakan nilai yang dianutnya kepada konseli (peserta didik yang dilayani), dan tidak boleh meneladankan diri untuk ditiru konselinya, melainkan memfasilitasi konseli untuk menemukan makna nilai kehidupannya (Sudrajat, 2011:2)

Strategi pendidikan karakter melalui pelayanan bimbingan dan konseling dapat dilakukan melalui: (1) layanan dasar; (2) layanan responsif; (3) perencanaan individual; dan (4) dukungan sistem. Strategi layanan dasar bimbingan merupakan pintu masuk bagi penyaluran pendidikan karakter melalui proses dan aktivitas bimbingan klasikal untuk membantu pemenuhan kebutuhan semua siswa terhadap penanaman nilai-nilai karakter. Perjumpaan interaktif di kelas antara konselor/guru BK dengan peserta didik secara rutin/terjadual sangat dibutuhkan dalam mana kesempatan itu sangat berguna untuk memberikan layanan preventif dan pengembangan diri. Kehadiran konselor tidak dapat direduksi hanya sekedar untuk melaksanakan layanan konseling bagi peserta didik bermasalah (Gysbers, 2004; Gysbers dan Henderson, 2000; Sink dan Stroh, 2003; Lapan, 2001; Rowley, 2005), apalagi hanya sekedar sebagai penjaga tata tertib di sekolah.

\section{Layanan Bimbingan Klasikal Sebagai Sa- luran Pendidikan Karakter di SMP}

Layanan bimbingan klasikal/kelompok pada hakekatnya memiliki fokus perhatian pada terjadinya perubahan pengetahuan, sikap, peri- laku, dan nilai-nilai pada peserta yang dilayani. Kegiatan out-bound dan kegiatan pelatihan pengembangan diri sangat kental berisi kurikulum bimbingan karakter. Semua kegiatan tersebut memuat aspek-aspek dan pelaksanaannya mengikuti prinsip-prinsip prosedur pelatihan pengembangan diri.

Layanan bimbingan klasikal (classroom guidance activities) yang dilaksanakan di dalam atau di luar kelas pada umumnya dilaksanakan dalam satu rangkaian kegiatan experiential learning dengan prosedur: pengantar/instruksi $\rightarrow$ dinamika kelompok/group process $\rightarrow$ refleksi pengalaman $\rightarrow$ sharing pengalaman $\rightarrow$ perumusan niat (I statement) untuk berubah/perbaikan diri. Prosedur ini bertujuan untuk mengembangkan dimensi sosial-psikologis, keterampilan hidup, klarifikasi nilai, dan perubahan sikapperilaku individu dalam kelompok.

Proses layanan bimbingan klasikal atau bimbingan kelompok memiliki ciri-ciri kekhususan tertentu dalam pendekatan, metoda, dan strategi penyampaiannya. Dalam layanan bimbingan klasikal, pendekatan experiential learning lebih ditekankan, mengingat layanan bimbingan lebih menonjol muatan aspek afeksi (nilai, sikap), perilaku, dan nilai-nilai karakter. Pada layanan bimbingan klasikal, peserta kegiatan diharapkan lebih banyak berproses, aktif, reflektif, dan dinamis-group process or group dynamic principles. Dalam layanan bimbingan klasikal bagi siswa SMP penekanan hasil lebih pada aspek perubahan sikap, perilaku mandiri, nilai-nilai karakter, dan keterampilan hidup (life skills) yang mendukung pada sukses studi dan sukses bergaul (penyesuaian diri).

\section{METODE}

Penelitian ini merupakan penelitian pendahulun (preliminary study) dari rangkaian penelitian pengembangan yang didesain dengan mengadopsi model research Development and Diffussion (the $R, D, \& D$ Model) yang dikembangkan dengan mengikuti prosedur Educational $R \&$ D Cycle (Borg \& Gall, 1983). Sebagai fase investigasi awal, desain penelitian ini menggunakan pendekatan deskriptif-evaluatif model mixing method. Evaluasi keterlaksanaan 
dan hambatan-hambatan pendidikan karakter terintegrasi di SMP didekati dengan cara-cara kualitatif, sedangkan kajian hasil dan analisis need assessment nilai-nilai karakter didekati secara kuantitatif deskriptif.

Tempat penelitian ini adalah beberapa SMP di provinsi DIY, Jawa Tengah, Banten, dan Jawa Timur, yang real punya konselor sekolah dan melaksanakan pendidikan karakter secara terintegrasi dalam pembelajaran. Daftar SMP yang dilibatkan untuk penjajagan awal adalah (1) SMP Stella Maris, Bumi Serpong Damai, Tangerang Selatan; (2) SMP Negeri 4 Wates, Kulon Progo, DI Yogyakarta; (3) SMP Negeri 13 Yogyakarta; (4) SMP Negeri 6 Surakarta, Jawa Tengah; dan (5) SMPK Santa Maria II Malang, Jawa Timur. Subjek penelitian ini terdiri atas Kepala Sekolah pada 5 SMP, Konselor/Guru BK pada 5 SMP, Guru mata pelajaran (4 orang dari setiap SMP), Para orang tua peserta didik Kelas VII dan VIII dari ke 5 SMP, dan Peserta didik SMP kelas VII dan/atau VIII $(\mathrm{N}=650$ orang).

Teknik pengumpulan data diperoleh lewat wawancara mendalam, observasi, dokumentasi, focus group discussion, daftar isian atau angket, dan rekam proses dikenakan secara langsung kepada para guru dan konselor sekolah melalui kegiatan collaborative self-evaluation untuk memotret kondisi awal pra pengembangan, selama proses pengembangan, dan akhir implementasi pengembangan model. Selain itu, pengumpulan data juga dilakukan lewat survei pendapat siswa, guru, kepala sekolah; observasi partisipan; pengisian kuesioner, inventori, dan dokumentasi.

Untuk pengumpulan data penelitian ini digunakan berbagai instrumen. Panduan wawancara untuk mengases keterlaksanaan dan hambatan-hambatan pendidikan karakter, skala semantic differensial untuk mengases hasil-hasil pendidikan karakter terintegrasi di SMP, instrumen untuk assessmen kebutuhan peserta didik, orang tua, guru berkaitan dengan kebutuhan-kebutuhan pendidikan karakter peserta didik. Uji kualifikasi instrumen dilakukan antara lain dengan focus group discussion, expert judgment validation, dan uji reliabilitas Alpha
Cronbach. Ditemukan indeks reliabilitas 0,89. Untuk mengases keterlaksanaan, hambatan dan daya dukung pendidikan karakter terintegrasi (existing program) di SMP dikenakan analisis kualitatif paradigma kuantitatif dengan teknik deskriptif yang disajkan dalam form matriks model phrase matrix, sedangkan untuk menganalisis hasil pendidikan karakter terintegrasi dikenakan analisis kuantitatif deskriptif-kategorial

\section{HASIL DAN PEMBAHASAN \\ Pelaksanaan Pendidikan Karakter Terinte- grasi di SMP}

Pada kelima SMP yang diobservasi, pendidikan karakter terlaksana dalam berbagai variasi sebagaimana ditunjukkan pada Tabel 1 . Keterlaksanaan pendidikan karakter berlangsung dalam ragam variasi kegiatan yang berbeda-beda pada sekolah satu dengan sekolah lainnya. Sekolah-sekolah negeri cenderung hanya memedomani rambu-rambu pelaksanaan pendidikan karakter terintegrasi yang dikeluarkan oleh pemerintah (Buku Pedoman Pendidikan Karakter di SMP, Direktorat Pembinaan SMP, 2010) dengan berorientasi pada pengintegrasian pendidikan karakter ke dalam kegiatan pembelajaran di kelas sebagai satu-satunya pedoman. Dalam perencanaan, setiap guru harus mencantumkan nilai-nilai karakter (dipilih dari daftar 20 nilai karakter yang diprioritaskan) yang relevan dengan pokok bahasan dalam RPP pada setiap mata pelajaran. Strategi ini, menurut pengakuan hampir semua guru mata pelajaran menjadikan implementasi pendidikan karakter terhenti pada tataran angan-angan. Tertulis indah dan rapi dalam RPP, tetapi miskin dalam aksinya. Cara inilah yang disindir banyak kalangan sebagai sistem pendidikan karakter "tempelan". Kenyataan ini memperkuat selorohan Buchori (2007), "Ungkapan character building kini sudah klise kosong, nyaris tidak bermakna. Diucapkan para politisi, birokrat pendidikan, pemimpin organisasi pendidikan, ungkapan ini tidak meninggalkan bekas apa-apa." 
Tabel 1. Pelaksanaan Pendidikan Karakter di SMP

\begin{tabular}{|c|c|c|}
\hline Sekolah & Manajemen PK & Pelaksanaan PK \\
\hline $\begin{array}{l}\text { SMP Stella } \\
\text { Maris BSD, } \\
\text { Tangerang }\end{array}$ & $\begin{array}{l}\text { Terintegrasi dalam } \\
\text { mapel tertentu, pro- } \\
\text { gram BK, dan ke- } \\
\text { giatan spiritualitas. } \\
\text { Kombinasi PK dari } \\
\text { pemerintah dan visi- } \\
\text { misi sekolah, educare } \\
\text { in caritatem, Guru BK } \\
\text { berperan pokok. }\end{array}$ & $\begin{array}{l}\text { - } 12 \text { nilai learner } \\
\text { profile } \\
\text { - } \text { poin modifikasi } \\
\text { perilaku } \\
\text { - } \text { mobile counseling } \\
\text { - LKDS, Retreet } \\
\text { - Pendseksualitas } \\
\text { - Pend Budi Pekerti } \\
\text { - Morning Assembling }\end{array}$ \\
\hline $\begin{array}{l}\text { SMP N } 4 \\
\text { Wates, } \\
\text { Kulon Progo }\end{array}$ & $\begin{array}{l}\text { Mengikuti Panduan PK } \\
\text { dari pemerintah, visi- } \\
\text { misi sekolah, PK } \\
\text { tempelan di RPP, buku } \\
\text { rapor kepribadian, }\end{array}$ & $\begin{array}{l}\text { - tadarus di sekolah } \\
\text { setiap pagi } \\
\text { - Jumat bersih \& sehat } \\
\text { - Koperasi sekolah }\end{array}$ \\
\hline $\begin{array}{l}\text { SMP N } 13 \\
\text { Yogyakarta }\end{array}$ & $\begin{array}{l}\text { Terprogram dan } \\
\text { insidental, mengikuti } \\
\text { pedoman PK dari pe- } \\
\text { merintah, PK tempel- } \\
\text { an di RPP, implemen- } \\
\text { tasi visi-misi sekolah, } \\
\text { senyum salam sapa, } \\
\text { BK masuk kelas } 1 \text { jp, } \\
\text { film-film karakter. }\end{array}$ & $\begin{array}{l}\text { - Salam pagi, doa } \\
\text { pagi, baca kitab suci } \\
\text { - Ekskul, pramuka } \\
\text { - Upacara bendera } \\
\text { - Peringatan hari-hari } \\
\text { nasional dan agama } \\
\text { - Classmeeting } \\
\text { - Melayat, tilik guru/ } \\
\text { teman sakit }\end{array}$ \\
\hline $\begin{array}{l}\text { SMP N } 6 \\
\text { Surakarta, } \\
\text { Jawa Tengah }\end{array}$ & $\begin{array}{l}\text { PK melalui pembela- } \\
\text { jaran, tetapi PK tem- } \\
\text { pelan di RPP, pena- } \\
\text { nganan kasus oleh } \\
\text { BK, ada } 18 \text { "SPIRIT", } \\
\text { salam pagi dengan } \\
\text { guru piket }\end{array}$ & $\begin{array}{l}\text { - Guru BK masuk } \\
\text { kelas } \\
\text { - PK menempel da- } \\
\text { lam pembelajaran } \\
\text { - Prakteknya masih } \\
\text { sekenanya saja } \\
\text { - Tayangan film } \\
\text { karakter }\end{array}$ \\
\hline $\begin{array}{l}\text { SMP Santa } \\
\text { Maria II } \\
\text { Malang, } \\
\text { Jawa Timur }\end{array}$ & $\begin{array}{l}\text { Enam pilar (dirancang } \\
\text { bersama 51 sekolah } \\
\text { Perkumpulan Dharma } \\
\text { Putri, masuk RPP, ada } \\
\text { teamwork untuk pro- } \\
\text { gram, Sekolah Unggul } \\
\text { Berbasis Nilai, } \\
\text { Spiritualitas SPM, } \\
\text { ISO 2001-2008 dari } \\
\text { Australia, }\end{array}$ & $\begin{array}{l}\text { - Ke } 6 \text { pilar diurai } \\
\text { dalam program } \\
\text { tahunan, tiap tahun } \\
\text { tekanan beda, mis: } \\
2014 \text { "ketangguhan" } \\
\text { - Tampung keluh-sa- } \\
\text { ran orangtua (kotak } \\
\text { masalah) } \\
\text { - Tanggap masalah } \\
\text { (maks } 3 \text { hari) } \\
\text { - Pembiasaan dan } \\
\text { keteladanan } \\
\text { - Doa pagi, pembaca- } \\
\text { an janji siswa, mela- } \\
\text { gukan Mars setiap } \\
\text { awal pelajaran pagi } \\
\text { - Moving class } \\
\text { - Tolong, maaf, terima } \\
\text { kasih } \\
\text { - Sabtu Solider } \\
\text { - Siswa absen atau ter- } \\
\text { lambat, sekolah } \\
\text { menelpon }\end{array}$ \\
\hline
\end{tabular}

Pada kasus penelitian ini, sekolah-sekolah swasta nasional tampak lebih kaya dan variatif dalam ragam aksi implementasi pendidikan karakter di sekolah. Manajemen sekolah dan para guru di sana lebih kreatif dalam mengeksplorasi bentuk-bentuk dan wahana implementasi pendidikan karakter di sekolah mereka selain mengintegrasikan penanaman nilai-nilai karakter dalam pembelajaran mata pelajaran di latar kelas. Bentuk-bentuk dan saluran kegiatan penanaman nilai karakter yang dipilih juga bersifat embided dalam aktivitas pesta sekolah yang secara tradisional dilestarikan. Untuk menjadi seseorang yang berkarakter, para peserta didik tidak harus dibawa ke suasana asing dengan menyelenggarakan kegiatan-kegiatan dadakan yang mengada-ada. Mereka membudayakan keberlangsungan retreet, rekoleksi, latihan kepemimpinan, perayaan ulang tahun sekolah, misa (ibadah) rutin bulanan, renungan pagi setiap mengawali kegiatan kelas, pendidikan seksualitas, dan lain-lain sebagai sarana pembiasaan. Sekolah-sekolah ini secara konsisten menegakkan semboyan, "all for character and then character for all".

Kenyataan bahwa pada sekolah-sekolah swasta nasional pelaksanaan pendidikan karakter berlangsung secara lebih bertanggung jawab dapat dipahami dalam konteks budaya moral komunitas. Bagaimana kita selanjutnya memikirkan sekolah sebagai lingkungan moral dan apa karakteristik lingkungan sekolah yang kondusif bagi perkembangan nilai dan moral. Itulah pertanyaan yang selalu berkecamuk dalam benak para manajerial dan para guru di sekolahsekolah Katholik. Mereka menerima dan memberi tempat yang penuh bagi setiap peserta didik sebagai anggota komunitas.

Kekayaan bentuk-bentuk dan variasi ragam saluran pendidikan karakter yang dimplementasikan pada sekolah-sekolah swasta nasional dibandingkan dengan minimnya pilihan cara penanaman nilai-nilai karakter di sekolah-sekolah negeri juga dapat ditelusuri sebagai dampak positif pelibatan secara optimal peran guru BK atau konselor sekolah dalam perencanaan, pelaksanaan, dan pemantauan implementasi pendidikan karakter di sekolah. Peran guru BK 
pada sekolah-sekolah negeri tidak dilibatkan secara penuh dalam perencanaan dan implementasi pendidikan karakter di sekolah. Hal ini bermula dari ketaatan membabi buta para manajerial dan staf sekolah negeri terhadap Pedoman Pendidikan Karakter di SMP yang diperintahkan oleh Direktorat Pembinaan SMP (2010) sebagai standar minimal ketentuan pelaksanaan pendidikan karakter di sekolah yang di dalamnya sama sekali tidak menuliskan sepenggal katapun tentang keterlibatan guru BK atau Konselor dalam pendidikan karakter di sekolah.

Oleh karena itu, tidak mengherankan jika dalam kasus penelitian ini, pada tiga SMP negeri pelaksanaan pendidikan karakter sangat miskin dalam gagasan dan kering dalam aksinya. Para guru berkilah bahwa implementasi pendidikan karakter terintegrasi dalam pembelajaran dan sulit dalam penerapannya karena panduan yang diberikan pemerintah untuk mengatur hal itu sangat tidak operasional. Dalam hal ini, tidak dapat disangkal sinyalemen Suyanto (2011) yang berkomentar bahwa pendidikan karakter di sekolah, khususnya di SMP di seluruh tanah air selama ini baru menyentuh pada tingkatan pengenalan norma atau nilainilai, dan belum pada tingkatan internalisasi dan tindakan nyata dalam kehidupan seharihari. Para gurupun ramai-ramai membenarkan bahwa nilai karakter yang dicantumkan dalam RPP itu masih berhenti di tataran ceramah dan memberi nasihat saja.

\section{Hambatan Pelaksanaan Pendidikan Karak- ter Terintegrasi di SMP}

Berdasarkan data wawancara, hambatanhambatan umum yang dialami oleh kelima SMP dalam pelaksanaan pendidikan karakter adalah: (1) Pedoman Pendidikan Karakter dari Direktorat Pembinaan SMP (2010) tidak operasional; (2) integrasi nilai karakter melalui pembelajaran masih bersifat sekedar tempelan, sulit menerapkannya; (3) tidak tersedia alat dan cara evaluasi untuk mengukur ketercapaian karakter; (4) penanaman nilai karakter masih cenderung pada tataran kognitif/diceramahkan; (5) komitmen dan konsistensi para guru dalam menjaga gawang karakter tidak selalu sama, cenderung rapuh; dan belum tercipta kolaborasi yang baik antara para guru dan konselor/guru BK dalam implementasi pendidikan karakter.

\section{Takaran Hasil Pendidikan Karakter}

Dengan menerapkan kriteria (PAP): $\geq 7,0$ $=$ Baik; 6,0-6,9 = Cukup; 5,0-5,9= Kurang baik; $<5,0=$ Buruk; pada skala 9 , maka tergambar capaian hasil pendidikan karakter pada siswa kelas VII $(\mathrm{N}=327)$ dan kelas VIII $(\mathrm{N}=$ 326) pada kelima SMP ditunjukkan pada Tabel 2.

Tabel 2. Sebaran Subjek Berdasarkan Kategori Tingkat Capaian Hasil Pendidikan Karakter

\begin{tabular}{lcccc}
\hline \multicolumn{1}{c}{ Kategori } & Kelas VII & $\%$ & Kelas VIII & $\%$ \\
\hline Buruk & 3 & 0,9 & 10 & 3,1 \\
Kurang Baik & 83 & 25,4 & 142 & 43,4 \\
Cukup Baik & 185 & 56,6 & 150 & 45,9 \\
Baik & 56 & 17,1 & 24 & 7,3 \\
$\quad$ Jumlah & 327 & 100 & 326 & 100 \\
\hline
\end{tabular}

Dengan menerapkan kriteria penilaian yang sama dengan Tabel 2, tergambar distribusi capaian skor butir pendidikan karakter sebagaimana dapat dilihat pada Tabel 3.

\section{Tabel 3. Sebaran Capaian Skor Butir Hasil Pendidikan Karakter}

\begin{tabular}{lcc}
\hline \multicolumn{1}{c}{ Kategori } & Kelas VII & Kelas VIII \\
\hline Buruk & 5 & 5 \\
Kurang Baik & 10 & 20 \\
Cukup Baik & 20 & 16 \\
Baik & 15 & 9 \\
$\quad$ Jumlah & 50 & 50 \\
\hline
\end{tabular}

Daftar butir pengukuran hasil pendidikan karakter yang teridentifikasi capaian skornya pada kategori kurang baik dan buruk pada siswa kelas VII dan VIII, misalnya pernyataan-pernyataan yang berbunyi sebagai berikut.

- Saya berbohong disaat terdesak/kepepet.

- Keteraturan waktu makan setiap hari.

- Keteraturan saya berolahraga setiap hari. 
- Saya menyesal jika melanggar tata tertib sekolah, tapi jika dalam keadaan terdesak saya melakukan hal itu (melanggar tata tertib).

- Mengerjakan tugas piket kelas sesuai dengan jadwal yang telah ditentukan.

- Mengerjakan tugas sendiri tanpa bantuan orang lain.

- Membuat suatu hasil karya yang memiliki nilai tinggi.

Dilihat dari hasilnya, implementasi pendidikan karaketr terintegrasi di SMP, efektivitasnya belum menggembirakan. Temuan evaluatif secara empirik menunjukkan bahwa 36,4\% dari 653 siswa SMP di 5 kota yang diteliti masih berada pada kategori kurang baik dan beberapa di antaranya buruk dalam capaian skor karakternya. Hanya 12,3\% dari 653 siswa tersebut yang masuk pada kategori baik dengan capaian skor $\geq 7$ pada skala stannine. Apa yang menyebabkan hasil rendah ini? Selain pedoman yang tidak operasional dalam implementasi pendidikan karakter terintegrasi dengan pembelajaran, para guru berhenti sekedar "menempelkan" nilai karakter pada RPP tanpa aksi nyata, penanaman nilai karakter masih berhenti pada tataran pengenalan kognitif dengan caracara ceramah.

Agung (2011:393) mensinyalir salah satu sebab dari lemahnya proses pembelajaran dalam implementasi pendidikan karakter bersumber dari kekurangmampuan guru dalam menciptakan proses pembelajaran yang mendukung. Berdasarkan pengamatan di lapangan ditegaskannya bahwa:

The current learning process at school does not develop the students' creativity, particularly in the social studies (IPS). Many educators are still implementing the conventional method in the learning process in class, resulted in an uninteresting learning process and dominated by the teacher. The learning process implemented by most educators today is only aiming to conclude the curriculum materials, more to memorizing than understanding the concept. This can be seen in the learning process in the class which is always dominated by teachers. In conveying the materials, the teacher is usually using the lecturing method, which the students needs only to sit, take note, and listen to what the teacher says, and there is a little chance for the students to ask.

Implementasi pendidikan karakter belum menyentuh dimensi penghayatan afektif dan masih jauh dari tataran pengamalan nilai secara nyata dalam tindak perilaku hidup terpelajar sehari-hari. Konsep dasar yang dipergunakan sebagai orientasi pendidikan karakter di Indonesia juga tidak jelas ujung pangkalnya. Dari mana berangkatnya dan mau ke mana pendidikan karakter dibawa, landasan filosofisnya tidak mudah ditemukan. Arthur (2014:205) mengamati bahwa gerakan pendidikan karakter ini tidak memiliki perspektif teoretis dan dasar praktek bersama.

Penerapan sistem poin yang berasumsi bahwa pelanggaran-pelanggaran 'kejahatan' siswa harus dihitung, dicatat, dan ditakar sangat tidak berakar dan tidak memanusiakan. Mengambil pandangan yang sepenuhnya negatif pada anak dengan menganggap bahwa anak dilahirkan berdosa dan jahat dan tugas pendidikan untuk memperbaiki ini melalui hukuman dan melatih ketaatan merupakan langkah awal kekeliruan dalam penerapan sistem poin. Pendekatan ini sering abstrak dan tidak banyak menjelaskan pada guru tentang paktek pedagogis pembentukan karakter.

Kekurangberhasilan pendidikan karakter melalui sistem pengajaran langsung (terintegrasi) juga dapat disebabkan karena semakin kuatnya relativisme moral masyarakat. Praktekpraktek mafia peradilan adalah salah satu contoh gamblang fenomena relativisme moral. Televisi dan media massa mempertontonkan dengan telanjang bagaimana pengacara membela seorang pembunuh agar dibebaskan dari tuduhan kejahatan. Akibatnya, Chapman (2011:13) menegaskan: "Therefore, children are often confused and uncertain about appropriate or inappropriate behavior in a group setting. Children are raised from a young age in very different ways. Often, their views of what is right and wrong are tampered with by the media and other negative influences." 
Pada sisi lain, penyimpangan remaja dari 'karakter baik' harus dilihat dalam konteks latar belakang perpecahan keluarga, kekerasan dalam rumah tangga, kemiskinan, dan gempuran terusmenerus tayangan kekerasan dan kenikmatan seks di media dan internet. Dalam hal ini, Chapman (2011:13) menambahkan: "Unfortunately, some children are never taught right from wrong from their parents. Parents are not disciplining enough, but instead are trying to be their child's best friend. Many parents do not recognize the importance of sound, thoughtful, and deliberate parenting choices. They are afraid of upsetting their child."

Sebagai akibat dari hal ini, semakin banyak siswa yang berangkat ke sekolah dengan menunjukkan gejala kecemasan, kelabilan emosi, dan perilaku agresif. Mereka tampaknya tidak memiliki banyak keterampilan sosial dan mengalami rendah diri. Semua ini memiliki efek umum mengurangi secara signifikan kemampuan sekolah untuk mengembangkan watak karakter yang positif.

Sementara itu, teridentifikasi 25 dari 50 butir pernyataan nilai karakter (berdasarkan skala pengukuran hasil pendidikan karakter yang diterapkan dalam penelitian ini) yang capaian skornya kurang baik dan 5 butir di antaranya bahkan dalam kategori buruk. Jiwa kewirausahaan, kemandirian, rasa ingin tahu, patuh pada peraturan sosial, dan menghargai karya/ prestasi orang lain teridentifikasi sebagai 5 nilai karakter yang capaiannya masih buruk. Temuan ini agaknya dapat melengkapi hasil penelitian Nurgiyantoro dan Efendi (2013:382) yang menemukan nilai-nilai religius, jujur, cinta tanah air, peduli lingkungan, tanggung jawab, kreatif, gemar membaca, disiplin, dan mandiri sebagai nilai yang diprioritaskan oleh guru dalam penentuan nilai pendidikan karakter dalam pembelajaran sastra di SMP. Agak mencengangkan, terdapat nilai karakter tertentu yang belum berhasil dicapai oleh siswa kelas VIII yang banyaknya hampir dua kali lipat dibandingkan pada siswa kelas VII. Artinya, dengan meningkatnya kelas, usia kognitif, dan penalaran moral tidak serta merta semakin meningkat kematangan karakter siswa, bahkan dalam kasus ini, ca- paian nilai karakter siswa kelas VII lebih baik daripada capaian siswa kelas VIII.

\section{PENUTUP}

Pelaksanaan pendidikan karakter terintegrasi di SMP di tanah air kita masih menemukan banyak kendala, seperti panduan kurang operasional, nilai karakter dalam RPP sekedar tempelan tanpa kongkritisasi, sistem penilaian nilai karakter yang belum ditemukan, kurangnya kesamaan komitmen dan konsistensi para guru dalam menegakkan nilai-nilai karakter, dan tidak terjalinnya kolaborasi antara para guru mata pelajaran dengan guru BK dalam implementasi pendidikan karakter di sekolah. Keadaan ini membawa dampak pada efektivitas hasil pendidikan karakter yang belum menggembirakan. Beberapa nilai karakter masih buruk capaiannya. Oleh sebab itu, kehadiran konselor (guru BK) di SMP yang memiliki kompetensi pendidikan khusus sebagai ahli perancang dan pelaksana pendidikan nilai-nilai dan sikap (karakter) sudah sewajarnya dilibatkan dan dioptimalkan peransertanya sebagai mitra profesional bagi para guru mata pelajaran dalam mendesain dan melaksanakan pendidikan karakter terinte-grasi di kelas. Guru BK dalam masa pendidikan prajabatannya telah dibekali cara-cara, strategi, pendekatan, metode penyampaian, dan teknik-teknik yang spesifik yang padat nuansa psikologis dalam transformasi pendidikan karakter kepada peserta didik tentu memiliki kompetensi yang unggul dalam memfasilitasi keterlaksanaan pendidikan karakter secara efektif, efisien, dan optimal.

Dibutuhkan kebijakan yang mendukung ke arah revitalisasi peran konselor tersebut agar para pemegang otoritas sekolah dapat mengoperasionalkan sinergi peran konselor dengan para guru mata pelajaran dalam implementasi pendidikan karakter yang lebih berkualitas. Implementasi Kurikulum 2013 yang meletakkan ranah sikap sebagai output yang harus diperkuat dalam unjuk kerja dunia pendidikan rasanya memberi tempat strategis, terhormat, dan lebih luas bagi penguatan peran konselor di sekolah. Dengan demikian, optimalisasi pelaksanaan pendidikan karakter di sekolah haruslah menjadi 
komitmen utama para konselor di sekolah, khususnya pada jenjang pendidikan SMP.

\section{UCAPAN TERIMA KASIH}

Terima kasih penulis ucapkan kepada Direktur Ditlitabmas, Ditjen Dikti, Depdiknas atas pemberian dana penelitian Stranas tahun 2014 yang memungkinkan berlangsungnya tahapan penelitian pengembangan ini. Artikel ini merupakan sepenggal kecil dari rangkaian proses dan hasil penelitian yang dapat dikomunikasikan melalui jurnal ini. Terima kasih kami sampaikan kepada Ketua LPPMP UNY dan Dewan Redaksi Cakrawala Pendidikan yang berkenan memberikan ruang berbagi untuk memublikasikan artikel ini kepada khalayak akademis. Semoga bermanfaat.

\section{DAFTAR PUSTAKA}

Agung, Leo. 2011. "Character Education Integration in Social Studies Learning". HISTORIA: International Journal of History Education, Vol. XII, No.2, Dec., 392-403.

Ahman. 1998. "Bimbingan Perkembangan: Model Bimbingan dan Konseling di Sekolah Dasar”. Disertasi (Tidak Diterbitkan). Bandung: Program Pascasarjana Institut Keguruan dan Ilmu Pendidikan.

Arthur, J. dalam Larry P. Nucci \& Darcia Narvaez. 2014. Handbook Pendidikan Moral dan Karakter. Bandung: Nusa Media.

Astuti, Siti I. 1999. Reformasi Pendidikan untuk Mengurangi Perilaku Anarki dan Menuju Masyarakat Madani”. Cakrawala Pendidikan. XVIII (3), Juni, hlm. 93-99.

Borg, W.R. \& Gall, M.D. 1983. Educational Research: An Introduction. New York \& London: Longman.

Buchori, Mochtar. 2007. "Character Building dan Pendidikan Kita". http://paramadina.Word-press.com/ 2007/03/04/character-building-dan-pendidikan-kita/ Diunduh 20 Mei 2012.
Chapman, A.M. 2011. "Implementing Character Education into School Curriculum," ESSAI: Vol. 9, Article 11. http://dc.cod.edu/essai.

Gysbers, N.C. \& Henderson, P. 2000. Developing and Managing Your School Guidance Program $\left(3^{\text {rd }}\right.$ ed.). Alexandria, VA: American Counseling Association.

Gysbers, N.C. 2004. "Comprehensive Guidance and Counseling Programs: The Evolution of Accountability". Professional School Counseling, 8(1), 1-14, Oct, 2004.

Lapan, R.T. 2001. "Results-Based Comprehensive Guidance and Counseling Programs: A Framework for Planning and Evaluation". Professional School Counseling, 4 (4), 289-298.

Lickona, Thomas. 2014. Pendidikan Karakter, Panduan Lengkap Mendidik Siswa Menjadi Pintar dan Baik. Bandung: Nusa Media.

Nurgiyantoro, Burhan \& Efendi, Anwar. 2013. "Prioritas Penentuan Nilai Pendidikan Karakter dalam Pembelajaran Sastra Remaja". Cakrawala Pendidikan, Jurnal Ilmiah Pendidikan, Th. XXXII, Nov., hlm. 382-393.

Plomp, T. 1999. Design Methodology and Developmental Research in/on Education and training. Twente University. Netherlands.

Raybum, C. 2004. "Assessing Students for Morality Education: A New Role for School Counselors". Professional School Counseling, 7 (5), 356-362.

Rowley, W.J. 2005. "Comprehensive Guidance and Counseling Programs Use of Guidance Curricula Materials: A Survey of National Trends". Professional School Counseling, 8 (3), 256-263. 
Sink, C.A. \& Stroh, H.R. 2003. Raising Achievement Test Scores of Early Elementary School Students through Comprehensive School Counseling Programs". Professional School Counseling, 6 (6), 350-357, Jun, 2003.

Sudrajat, Akhmad. 2011. "Pendidikan Karakter dalam Layanan Bimbingan dan Konseling" dalam http://akhmad sudrajat.wordpress. com/2011/10/07/ Diunduh Tanggal 15 Okt 2011.
Supriyadi, Edy. 2009. "Pengembangan Pendidikan Karakter di SMP”. Makalah Diskusi Pengembangan Panduan Pendidikan Karakter Direktorat Pembinaan SMP Depdiknas.

Suyanto. 2010. Panduan Pendidikan Karakter di Sekolah Menengah Pertama. Jakarta: Direktorat Pembinaan SMP, Ditjenmandikdasmen.

Winkel, W.S. \& Hastuti, Sri. 2004. Bimbingan dan Konseling di Institusi Pendidikan. Jakarta: Media Abadi. 